\title{
Thank You for the Opportunity
}

\section{A Bit of History}

In 1997 Williams \& Wilkins (soon to become Lippincott Williams \& Wilkins or LWW) agreed to publish a journal for the American College of Medical Genetics, and I had the good fortune of being selected founding Editor-in-Chief soon thereafter in 1998. At that point we had no name, office, manuscripts, or any real idea of what we were starting. Kristine Christopherson joined me as Managing Editor, and, after some discussion with many College members, the journal was named Genetics in Medicine. The next months involved establishing an Editorial Board, with its initial meeting in the fall of 1998 in Los Angeles, developing a mission statement and vision for GIM, and developing the manuscript solicitation and review procedures for selecting high-quality manuscripts for publication. Our initial contract with LWW called for publishing six issues per year, and, because we were anxious to get started, we published our first issue (Volume 1, Issue 1) in November/December, 1998. Volume 1 continued through 1999.

The process of establishing a new journal in a crowded field was complex, and the Editorial Board worked hard to make this happen. The Board felt that genetics played a central role in the practice of medicine through the prediction, prevention and management of disease and the promotion of public health (the vision thing) and our mission became the enhancement of the integration of genetic knowledge broadly in medical practice through the publication of work of the highest quality reporting innovative findings and their clinical application, and providing a forum for education in medical genetics. The Editorial Board also decided that there were several goals that should be achieved to have a successful journal. First, we had to publish on time, and we have done so since the start, primarily through the dedication of Kristine Christopherson and the support of LWW. Next, we needed to be indexed by Index Medicus and by the National Library of Medicine for MEDLINE. Both of these milestones were achieved in 2001. And finally, the Impact Factor for GIM had to be respectable, and this goal has been reached. GIM also became the mechanism for publication of the increasingly important ACMG statements and guidelines. Along the way we published our first supplement (2002), added additional Editors (Law and
History), and moved to online submission (2004) and then to online submission and review (2005). In 2006 we moved to publishing monthly, with Volume 8 the first to have 12 issues. Through all of this LWW has provided great support for the Editorial Office and Board, as well as help and insight with various publishing issues beyond our knowledge.

\section{Thank You}

This final editorial gives me the opportunity to thank all of the people who have added to this adventure. The founding Editorial Board which consists of Allen Bale, Suzanne Cassidy, Jessica Davis, Louis Skip Elsas, Lynn Fleisher, Jan Friedman, Karen Greendale, Muin Khoury, Bruce Korf, Vincent Riccardi, Jerry Rotter, and Stuart Schwartz has worked hard at every step of our development. Their input, support, and thoughtfulness have been wonderful for me and important for GIM. They deserve a public thank you for their work on Genetics in Medicine.

There is always one critical person in all successful endeavors, and Kristine Christopherson has been that person for GIM and for me. She has worked more than full-time to produce a polished, finished product and has been the friendly, helpful voice of GIM to all of the authors, the publisher, and other correspondents. GIM would not be where it is today without Kristine, and she deserves a thank you from all College members and GIM readers.

Finally, I would like to thank College itself, for giving me this opportunity. Being Editor-in-Chief for a new journal has been an amazing and fascinating learning experience. We all need to grow, and GIM has been wonderful for me. I thank the Board of Directors for their encouragement and support, the authors for submitting their manuscripts, the publisher LWW for being part of the process, and the American College of Medical Genetics for the opportunity to be the Founding Editor-inChief. It has been a great ride and I have enjoyed every part of the process. 